\title{
Flavor Trivia and Tomato Aroma: Biochemistry and Possible Mechanisms for Control of Important Aroma Components
}

\author{
Elizabeth A. Baldwin ${ }^{1}$ \\ U.S. Department of Agriculture, Agricultural Research Service, Citrus and Subtropical Products Laboratory, \\ Winter Haven, FL 33883-1909 \\ John W. Scott \\ University of Florida Gulf Coast Research Center, Bradenton, FL 34203 \\ Christine K. Shewmaker \\ Calgene, Inc., 1920 Fifth Street, Davis, CA 95616 \\ Wolfgang Schuch \\ Zeneca Plant Science, Jealotts Hill Research Station, Bracknell, Berkshire RG426ET, UK
}

\begin{abstract}
Consumers are often dissatisfied with the flavor of fresh tomatoes (Lycopersicon esculentum Mill.) purchased in the supermarket. There are several reasons for this, ranging from poor genetic material to harvest and handling procedures. Research is ongoing to determine the important flavor components in tomato in order to give breeders and molecular biologists access to objective flavor criteria for use in selection of high-quality material. Furthermore, harvest and postharvest handling, and shipping and storage procedures can be analyzed for their effects on important flavor components.
\end{abstract}

\section{FLAVOR TRIVIA}

To successfully conduct this research, one must first understand what comprises flavor and how it is perceived. The nose has olfactory nerve endings at the back with receptors that bind volatiles emanating from food. These reactions are somewhat analogous to enzyme/ substrate stereochemical associations. Tastes such as sweet, sour, salty, or bitter are perceived because of reactions of sugars or polyalcohols, hydronium ions, sodium ions, glucosides , alkaloids, etc., with receptors located in certain regions of the tongue. The nerves in the tongue can also detect texture, temperature, metallic irritation, bite (carbonation), chemical heat [e.g., hot pepper (Capsicum fruitescens L.)], etc., collectively known as trigeminal responses. The olfactory system is the more sensitive of the two organs, however, and the most sensitive of the five senses. It can detect odors in parts per trillion whereas receptors on the tongue can detect flavor compounds in parts per hundred. The adverse side of this extreme sensitivity is fatigue, which may be a protective mechanism against nerve damage (DeRovira, 1997). Nevertheless, the fatigue factor must be considered in sensory work with aroma compounds.

The extreme sensitivity of the olfactory organ has played an important role in the evolutionary development of mammals, allowing for the odor imprinting involved in olfactory recognition. This has helped in developing behavioral relationships, such as mother-offspring, consort interactions, and general kin recognition, not to mention detection of predator and prey (Margot and Salvadori, 1995;

Received for publication 7 Sept. 1999. Accepted for publication 4 Jan. 2000 Mention of a trademark or proprietary product is for identification only and does not imply a guarantee or warranty of the product by the U.S. Dept. of Agriculture. All programs and services of the U.S. Dept. of Agriculture are offered on a nondiscriminatory basis without regard to race, color, national origin, religion, sex, age, marital status, or handicap. The cost of publishing this paper was defrayed in part by the payment of page charges. Under postal regulations, this paper therefore must be hereby marked advertisement solely to indicate this fact.

${ }^{1}$ South Atlantic Area, Agricultural Research Service, U.S. Dept. of Agriculture; e-mail address: ebaldwin@ citrus.usda.gov.
Rouhi, 1996). Specific odors can evoke powerful thoughts and emotions in humans. The sense of smell, therefore, has played a key role in several areas important to species survival. In mammals at least 1000 receptor genes are devoted to encoding receptors that recognize odors; these comprise $1 \%$ to $2 \%$ of the mammalian genome (Rouhi, 1996).

Many factors can affect our perception of flavor, especially the components of flavor made up of aroma compounds. Smelling an aromatic food through the front of the nose may produce a different experience than when the aroma is perceived during chewing of food (Voirol and Daget, 1987). This difference is due to the temperature of the mouth, the disruption of food cells by chewing, and reduction of viscosity by mixing the food with saliva. Temperature, viscosity, and polarity of the food can effect relative vapor pressure and aroma release (Land, 1994; Taylor and Linforth, 1994; Voirol and Daget, 1987). This, in turn, alters the concentration in the headspace of the mouth of volatile compounds that rise through the back of the nose to bind olfactory receptors (Land, 1994; Taylor and Linforth, 1994). In addition, odor and taste can interact to give an integrated perception (Voirol and Daget, 1987). Texture can also play a role. A softer tomato may be perceived as more flavorful than a firm tomato, while a crisp, juicy apple will likely be perceived as more flavorful than a mealy one. Such observations may be related to texture and the state of the cell wall (in particular, the condition of the middle lamella). The mechanism of tissue disruption, i.e., whether fruit cells break across cell walls, releasing cellular components, or between cells (middle lamellae) as in mealy fruit, may affect juiciness and flavor impact (Vickers, 1977).

To make matters more complicated, not all odorants are alike. Primary odorants are like letters of the alphabet in that they define one odor individually and can then, in combination, define another aroma. They bind only one receptor in the olfactory bulb. Methyl salicylate, an important volatile in tomato, is an example; it alone is responsible for the aroma "wintergreen." Secondary odorants are like syllables and bind more than one olfactory receptor (Amoore, 1952). An example would be safrole, which is thought to bind four receptors and is described as anise, with a wintergreen character, vanilla background, and camphoraceous overtone (= root beer flavor) (De Rovira, 1997). This food additive is carcinogenic and has been removed from the market. Manufacturers were able to duplicate its aroma by using a combination of primary odorants, including anise, methyl salicylate, vanillin and camphor, which bind the same four olfactory receptors as safrole. And finally, to really confound the issue, flavors have top notes and background notes. Top notes are generally compounds of relatively low molecular weight and high volatility that are heat labile and polar (De Rovira, 1997). They are usually very noticeable in a food item. Background notes, on the other hand, are generally of low molecular weight, heat stable, and nonpolar, and have a more subtle impact on flavor than do top notes. 


\section{IMPORTANT AROMA COMPOUNDS FOR TOMATO FLAVOR}

First, how do we measure odor compounds that are present in food? Earlier studies employed the classical flavor isolation procedures of steam distillation and/or solvent extraction (Teranishi and Kint, 1993), which can modify the flavor profile of a sample qualitatively and quantitatively (Schamp and Dirinck, 1982). This method is timeconsuming and not easily applied to large numbers of fruit samples. Internal standards must be incorporated to determine recovery, but the resulting concentration of material allows identification of compounds by gas chromatography-mass spectrometry (GC/MS). More recently, investigators have employed purge and trap headspace sampling methods, which involve trapping and concentrating volatile components on a solid support. The trap is later heated to release volatiles into GC or GC/MS systems (Schamp and Dirinck, 1982; Teranishi and Kint, 1993). Gas chromatographs may be equipped with a sniff port to provide some sensory information as the compounds are eluted from the column. Static headspace methods are said to more closely reflect the true flavor profile, however, although the compounds are present at lower levels and some may not be detected. Cryofocusing (cold trapping) of static headspace volatiles (Teranishi and Kint, 1993) can help overcome this problem, since samples can be concentrated without heating and the associated possibility of adulteration. The newest method available is solid phase microextraction (SPME), a rapid sampling technique where volatiles interact with a fiber-coated probe that is inserted into the headspace of a sample and then transferred to a GC injection port where the volatiles are desorbed (Song et al., 1998). Aside from GC and GC/MS methods, there are new sensors available that have a broad range of selectivity. These sensor arrays (called "electronic noses") are useful for discriminating one sample from another based on the volatile profile, rather than for identification/quantification (Maul et al., 1998a).

So now that aroma compounds can be identified and quantified, how do we know which ones are contributing to flavor? One way is to do aroma extraction dilution analysis (AEDA) or "Charm" analysis, using a sniff port on a GC while diluting the sample (Acree, 1993). A simpler method is to establish odor thresholds (Teranishi and Buttery, 1987; Teranishi et al., 1991). This is done in the food or in some similar medium since odorants' volatility can change with polarity and viscosity (Buttery et al., 1973). In tomato, for example, $>400$ volatiles have been reported, but only 30 are present in concentrations $>1 \mathrm{~nL} \cdot \mathrm{L}^{-1}$, as summarized in several reviews (Buttery, 1993; Buttery and Ling, 1993a, 1993b; Buttery et al., 1989). Buttery et al. (1971) determined odor thresholds (the level at which a compound can be detected by smell) for these 30 compounds. Log odor units can then be calculated from the ratio of the concentration of a component in a food to its odor threshold. Volatile compounds with positive odor units are assumed to contribute to the flavor of a food, while those with negative units may not (Buttery et al., 1989). Buttery (1993) determined concentrations, odor thresholds, and log odor units of volatiles present in tomato at levels of $1 \mathrm{~nL} \cdot \mathrm{L}^{-1}$ or more (Table 1 ). Of these, 16 had log odor units $>0$, and therefore are likely to contribute to tomato flavor. Some fruits or vegetables have one or two odor-impact compounds that dominate the flavor of that particular commodity. Banana (Musa acuminata Colla) is a good example, with 3-methylbutyl acetate dominating its flavor (Berger, 1991). Not so for tomato, however, since no single compound has been found in this fruit that is reminiscent of a ripe tomato; a combination of at least 16 aroma compounds together give tomato its unique odor characteristics. Buttery (1993) has suggested that a combination of cis-3-hexenal, cis-3-hexenol, hexanal, 1-penten-3one, 3-methylbutanal, trans-2-hexenal, 6-methyl-5-hepten-2-one, methyl salicylate, 2 -isobutylthiazole, and $\beta$-ionone, at the appropriate concentrations, produces the aroma of a fresh, ripe tomato. However, compounds with negative odor units may still contribute to the overall flavor of tomato or other foods as background notes. For this reason synthetic flavors, vanillin, for example, do not have quite the same aroma as the natural vanilla extract, which contains many background notes not present in the synthetic product.

Tomato volatiles present at concentrations $\geq 1 \mathrm{~nL} \cdot \mathrm{L}^{-1}$, along with their concentrations in a typical ripe tomato, odor threshold, and log odor units (Table 1) (Buttery, 1993), demonstrate that a volatile need not be present in high levels to have an impact on flavor. For example, cis-3-hexenal is the most abundant $\left(12,000 \mathrm{~nL} \cdot \mathrm{L}^{-1}\right)$ of the 30 volatiles present at $>1 \mathrm{~nL} \cdot \mathrm{L}^{-1}$, and has the highest log odor unit (3.7) (Table 1). However, $\beta$-ionone, a volatile present at one of the lowest concentrations $\left(4 \mathrm{~nL} \cdot \mathrm{L}^{-1}\right)$, is second highest in log odor units (2.8).

Odor thresholds in the above studies were determined in water, since tomato is considered an aqueous system. Tomato homogenate (which simulates masticated tomato), however, may bind or trap volatiles, and contains high levels of methanol and other alcohols (Baldwin et al., 1991a, 1991b) that could affect volatile solubility and, therefore, odor threshold. Threshold studies of tomato aroma compounds were carried out in an aqueous alcohol system (water with the amount of methanol and ethanol found in fresh tomato homogenate) and in bland homogenate (volatiles removed by distillation). Volatiles in homogenate generally had higher thresholds (i.e., suppressed sensory perception) and different odor descriptors than did those in water (Tandon, 1998).

Some investigators have attempted to determine the relationships of different flavor compounds (sugars, acids, and volatiles) to sensory descriptors in order to understand the contribution of individual components to overall flavor. Correlations were found between concentrations of aroma compounds and the intensity of aroma as well as taste descriptors (Baldwin et al., 1998). For example, geranylacetone was related to tomato-like flavor and sweetness whereas 6-methyl-5hepten-2-one was associated with tomato-like flavor, overall acceptability, and spoiled aroma. In three seasonal studies, sweetness intensity was related to hexanal, with contributions from cis-3-hexenal, trans-2-hexenal, or cis-3-hexenol. Soluble solids were more closely related to sourness than to sweetness, which, in turn, correlated more closely with sucrose equivalents (combined sweetness value of glucose and fructose).

Table 1. Tomato volatiles present in fresh tomato at levels $\geq 1 \mathrm{~nL} \cdot \mathrm{L}^{-1}$, their odor threshold (in water) and their order of log odor units. ${ }^{2}$

\begin{tabular}{|c|c|c|c|}
\hline Volatile & $\begin{array}{c}\text { Concn } \\
\left(\mathrm{nL} \cdot \mathrm{L}^{-1}\right)\end{array}$ & $\begin{array}{c}\text { Odor threshold } \\
\left(\mathrm{nL} \cdot \mathrm{L}^{-1}\right)\end{array}$ & $\begin{array}{c}\text { Log odor } \\
\text { units }^{y}\end{array}$ \\
\hline cis-3-Hexenal & 12,000 & 0.25 & 3.7 \\
\hline$\beta$-ionone & 4 & 0.007 & 2.8 \\
\hline Hexanal & 3,100 & 4.5 & 2.8 \\
\hline$\beta$-Damascenone & 1 & 0.002 & 2.7 \\
\hline 1-Penten-3-one & 520 & 1 & 2.7 \\
\hline 2+3-Methylbutanal & 27 & 0.2 & 2.1 \\
\hline trans-2-Hexenal & 270 & 17 & 1.2 \\
\hline 2-Isobutylthiazole & 36 & 3.5 & 1.0 \\
\hline 1-nitro-2-Phenylethane & 17 & 2 & 0.9 \\
\hline trans-2-Heptenal & 60 & 13 & 0.7 \\
\hline Phenylacetaldehyde & 15 & 4 & 0.6 \\
\hline 6-Methyl-5-hepten-2-one & 130 & 50 & 0.4 \\
\hline cis-3-Hexenol & 150 & 70 & 0.3 \\
\hline 2-Phenylethanol ${ }^{\mathrm{x}}$ & 1,900 & 1,000 & 0.3 \\
\hline 3-Methylbutanol & 380 & 250 & 0.2 \\
\hline Methyl salicylate & 48 & 40 & 0.08 \\
\hline Geranylacetone & 57 & 60 & -0.02 \\
\hline$\beta$-Cyclocitral & 3 & 5 & -0.2 \\
\hline 1-Nitro-3-methyl-butane & 59 & 150 & -0.4 \\
\hline Geranial & 12 & 32 & -0.4 \\
\hline Linalool & 2 & 6 & -0.5 \\
\hline 1-Penten-3-ol & 110 & 400 & -0.6 \\
\hline trans-2-Pentenal & 140 & 1,500 & -1.0 \\
\hline Neral & 2 & 30 & -1.2 \\
\hline Pentanol & 120 & 4,000 & -1.5 \\
\hline Pseudoionone & 10 & 800 & -1.9 \\
\hline Isobutyl cyanide & 13 & 1,000 & -1.9 \\
\hline Hexanol & 7 & 500 & -1.9 \\
\hline Epoxy- $\beta$-ionone & 1 & 100 & -2.0 \\
\hline
\end{tabular}

${ }^{2}$ Adapted with permission from Buttery (1993), copyright 1993, American Chemical Society.

'Logarithm of odor unit value.

xThe exact concentration and log odor unit values are uncertain. 


\section{SYNTHESIS OF TOMATO VOLATILES}

The biogenesis of aroma compounds in tomato has been the subject of several recent reviews (Buttery and Ling, 1993a, 1993b). Flavor volatiles are formed in the intact tomato fruit during ripening, or upon tissue disruption, which occurs when tomatoes are macerated, blended, or homogenized (Buttery, 1993). When cell disruption occurs, previously compartmentalized enzymes and substrates mix and new volatiles are formed. The ability to form flavor volatiles after cell disruption, however, can change during ripening, apparently because of changes in enzyme and substrate availability. To determine which volatiles are formed in intact tissue and which are formed after cell disruption, reactions were minimized by blending tomatoes in saturated calcium chloride $\left(\mathrm{CaCl}_{2}\right)$ or rapidly heated in a microwave to deactivate enzymes (Buttery, 1993; Buttery and Ling, 1993a). This assumes that enzymes were, in fact, deactivated immediately and that nonenzymatic oxidative reactions did not result in production of some volatiles. Volatiles present at $\geq 1 \mathrm{~nL} \cdot \mathrm{L}^{-1}$ that appeared when tissue was disrupted, those that increased upon tissue disruption, and those that showed little change are shown in Table 2 (Buttery and Ling, 1993a). Of those that appeared upon tissue disruption, only trans-2-pentenal was present in concentrations $>1 \mathrm{~nL} \cdot \mathrm{L}^{-1}$, although it has negative log odor units. Several of the volatiles that increased when tissue was disrupted, including the lipid oxidation compounds that are considered to be important to tomato flavor, had positive log odor units. All but two (1penten-3-ol and geranylacetone) had positive odor units; these two, nevertheless, were present at $>1 \mathrm{~nL} \cdot \mathrm{L}^{-1}$. For volatiles that showed little change during tissue disruption, all but three (pentanol, hexanol, and gerenial) had positive odor units and, thus, are likely to contribute to tomato flavor.

Volatile precursors include lipids, amino acids, carotenoids, and terpenoids (Buttery and Ling, 1993b) (Table 3). Volatiles are formed from lipids via oxidation when cells are disrupted. The enzyme lipoxygenase (LOX), along with hydroperoxide lyase (HPL) and a hydroperoxy cleavage enzyme, convert linoleic (18:2) and linolenic (18:3) acids to hexanal and cis-3-hexenal, respectively, via 9- and 13hydroperoxy- C18:2 and -C18:3 intermediates (Fig. 1). Hexanal and cis-3-hexenal can be reduced to hexanol and cis-3-hexenol, respectively, by a reductase enzyme such as alcohol dehydrogenase (ADH). Further isomerization of cis-3-hexenal to trans-2-hexenal can occur, either enzymatically or nonenzymatically (Galliard et al., 1977; Jadhav et al., 1972; Riley et al., 1996; Stone et al., 1975). This process is similar for tomato leaves and fruits (Buttery and Ling, 1993b; Galliard et al., 1977). The ability to form volatiles upon tissue disruption, however, changes during ripening (Fig. 2). Levels of hexanal, cis-3and trans-2-hexenal, formed after tissue homogenization, increase as the fruit ripens (Baldwin et al., 1991a).

Other volatiles arise from amino acid precursors, including alanine, valine, leucine, isoleucine, and phenylalanine (Table 3). This occurs mostly in the fruit during the ripening process rather than upon cell disruption. Tomato fruit contain some highly unusual, volatile, nitro compounds (Buttery, 1993), which are not found in any other fresh fruit or vegetable, but do occur in some flowers. They can, however, be formed by degradation of amino acids and sugars in cooked foods. They appear as tomatoes ripen from breaker to mature red stages. One proposed pathway is via an amino acid, such as phenylalanine, which can be converted to 1-nitro-phenylethane and thence to phenylacetaldehyde in vitro by reducing the $\mathrm{pH}$ from 10.0 to 4.5 (Nef reaction) (Buttery, 1993). The proposed pathway for phenylacetaldehyde and 3-methylbutanal, therefore, is from 1-nitro2-phenylethane and 1-nitro-3-methylbutane, perhaps by some enzymatic system in the fruit.

Alternatively, volatile aldehydes such as phenylacetaldehyde and 3-methylbutanal could be formed from enzymatic oxidation of corresponding alcohols that are released by enzymatic hydrolysis of glycosides during ripening. Glycosides can also be precursors of volatile aroma compounds (Williams, 1993). Isolation of a fresh tomato glycoside fraction yielded 3-methylbutyric acid and $\beta$-damascenone

Table 2. Volatiles present in tomato at levels $\geq 1 \mathrm{~nL} \cdot \mathrm{L}^{-1}$ that (A) appear after tissue disruption, (B) increase after tissue disruption, or (C) show no change after tissue disruption and are assumed to be present in the intact fruit. ${ }^{2}$

\begin{tabular}{lcc}
\hline \hline A) Appear after tissue disruption & B) Increase after tissue disruption & C) No significant change due to tissue disruption \\
\hline trans-2-Pentenal & cis-3-Hexenal & 3-Methylbutanol \\
& trans-2-Hexenal & Pentanol \\
& Hexanal & cis-3-Hexenol \\
& trans-2-Heptenal & Hexanol \\
& 1-Penten-3-one & 6-Methyl-5-hepten-2-one \\
& 1-Penten-3-ol & Phenylacetaldehyde \\
Geranial & Geranylacetone & 2-Phenylethanol \\
& 2-Isobutylthiazole & \\
\hline
\end{tabular}

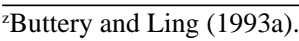

Table 3. Origins of tomato volatiles present in fresh tomato leaves (L), fruit (F) stems (S), and all plant parts ${ }^{2}$.

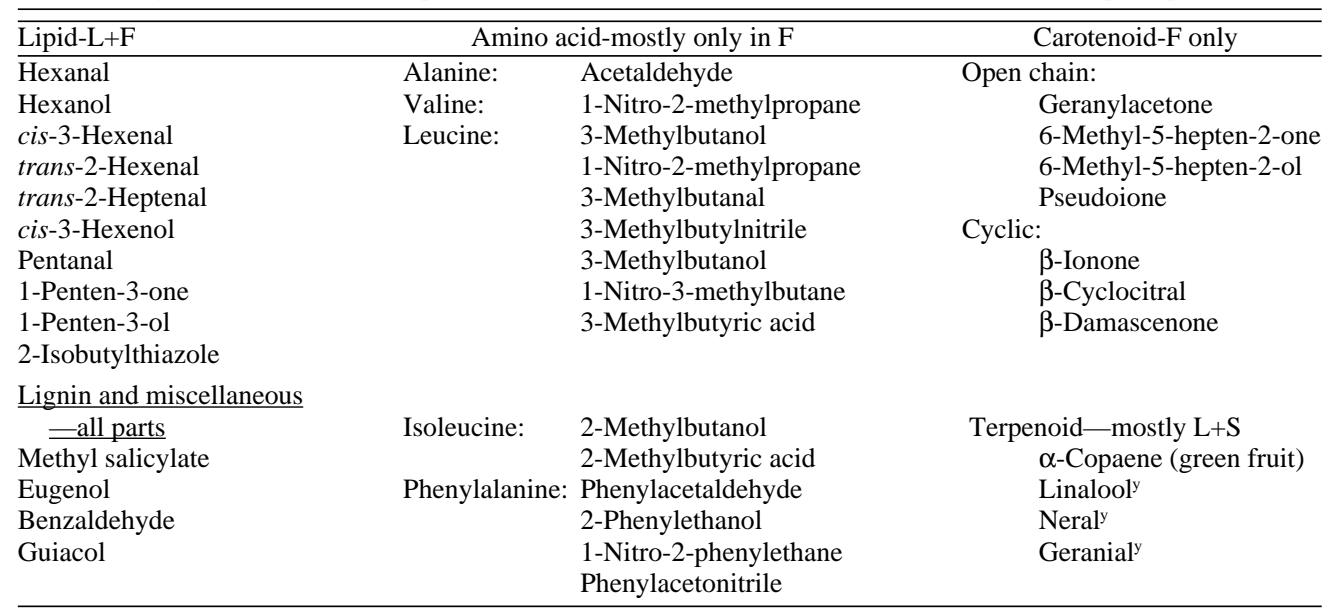

${ }^{2}$ Buttery and Ling (1993b).

yoxygenated. 


\section{ENZYMATIC DEGRADATION OF LIPIDS}
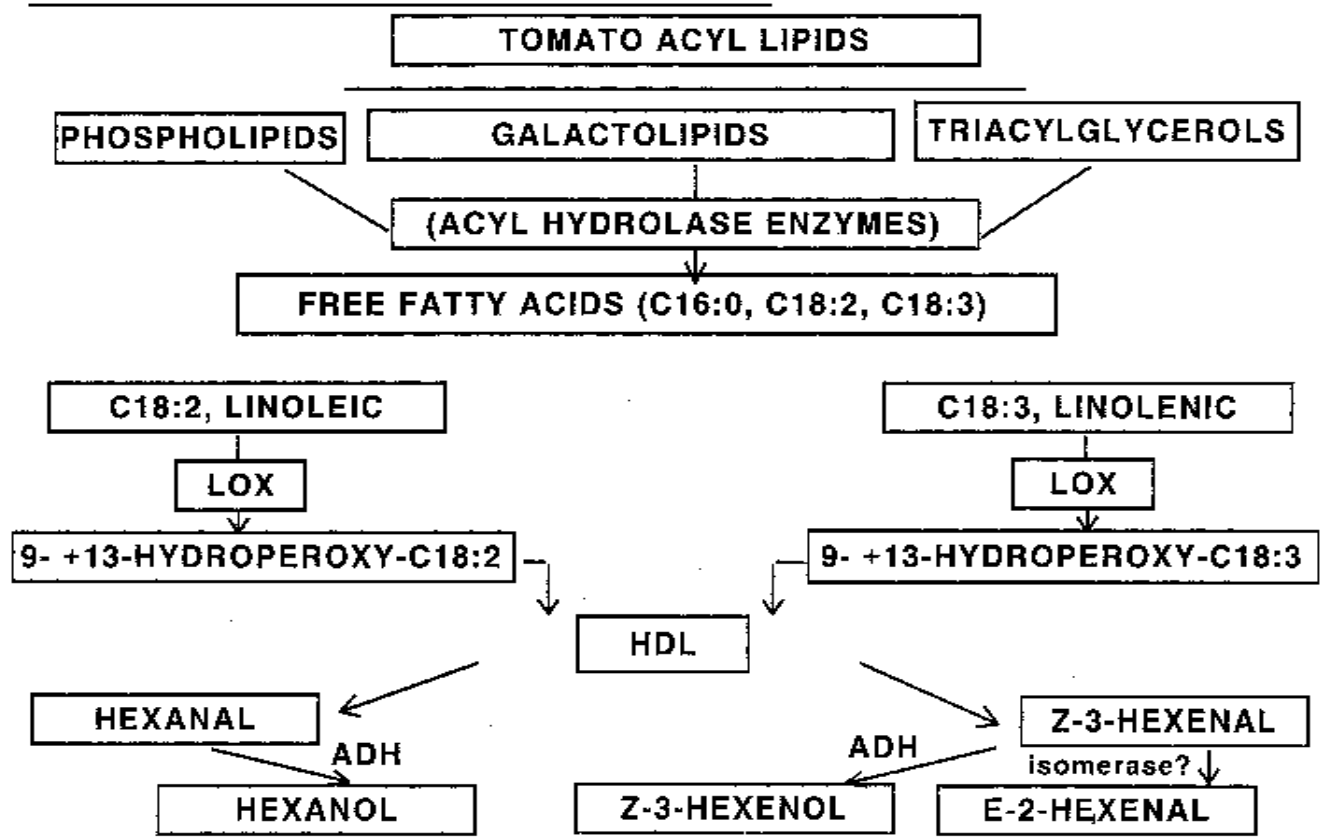

Fig. 1. Biosynthetic pathway for formation of $\mathrm{C}_{6}$ "green" aroma volatiles from degradation of acyl lipids in blended tomato fruit (Gallaird, et al., 1977; Riley et al, 1996). $\mathrm{LOX}=$ lipoxygenase, $\mathrm{HDL}=$ hydroperoxide lyase, and $\mathrm{ADH}=$ alcohol dehydrogenase.

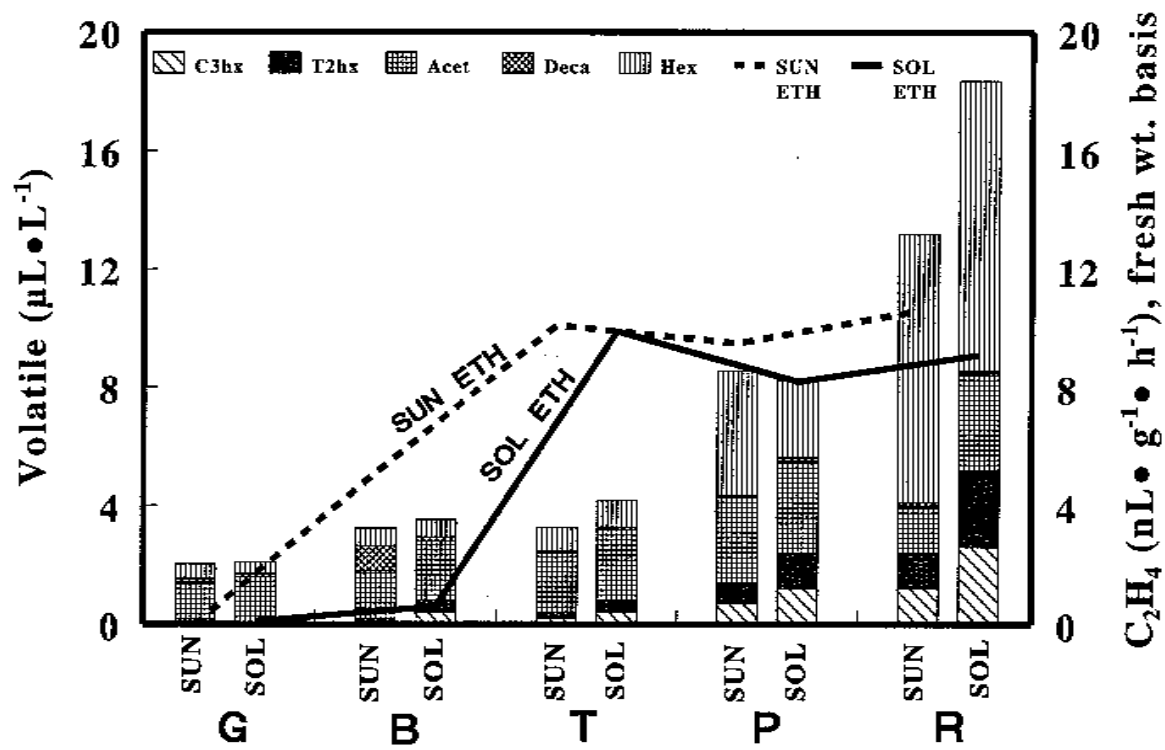

Fig. 2. Concentrations of aldehyde volatiles cis-3-hexenal (C3hx, HSD = 0.5), trans-2-hexenal (T2hx, HSD = 1.2 ), acetaldehyde (Acet, HSD = 1.0), trans-2-trans-4decadienal (Deca, HSD = 0.07), hexanal $(H e x$, HSD $=3.1)$, and ethylene $(E T H)$ production in homogenates of 'Sunny' $(S U N$ ETH) and 'Solar Set' $($ SOL ETH) tomatoes sampled at the mature green $(\mathrm{G})$, breaker $(\mathrm{B})$, turning $(\mathrm{T})$, pink $(\mathrm{P})$, and red $(\mathrm{R})$ ripening stages. Values are means for five replications. HSD (honestly significant difference) for ripening determined by Tukey's studentized range (after Baldwin et al., 1991a).

as major products upon hydrolysis. Other products included phenylacetaldehyde, 2-phenylethanol, linalool, linalool oxides, hotrienol, $\alpha$-terpineol, 4-vinylguaiacol, 4-vinylphenol (Buttery, 1993; Buttery et al., 1990). The volatile furaneol [2,5- dimethyl-4-hydroxy-3-(2H)-furanone] may also be formed from enzymatic hydrolysis of furaneol- glycoside during ripening, since its concentration is little affected by blending (Buttery et al., 1995). It has a pineapple-like odor and may contribute to flavor since it has relatively high odor units (1.4). Although hexanol, cis-3-hexenal, and 6methyl-5-hepten-2-one are also found after hydrolysis of glycosides, they are probably not bound as glycosides, but formed after blending (Buttery et al., 1990).

Carotenoids may also be precursors of some important flavor volatiles (Table 3) (Buttery and Ling, 1993a). They are formed from $\mathrm{C}_{8}, \mathrm{C}_{13}$, and $\mathrm{C}_{18}$ linear and cyclic isoprene $\left(\mathrm{C}_{5}\right)$ composites. This occurs only in the fruit and, in some cases, is dependent on cell disruption.

Finally, some volatiles are formed from terpenoids $\left(\mathrm{C}_{10}\right.$ and $\left.\mathrm{C}_{15}\right)$, related to lignin or of unknown origin (Table 3). Only one terpenoid volatile ( $\alpha$-copaene) has actually been identified in tomato fruit and occurred only in green fruit (Buttery and Ling, 1993b). However, several oxygenated terpenoid volatiles, which are important for flavor of other fruits, have been identified in ripe tomatoes, although their log odor units are below zero (linalool, neral, and geranial). Lignin-related and miscellaneous volatiles include methyl salicylate, eugenol, benzaldehyde, and guaiacol. Of these, only methyl salicylate has log odor units $>0$. 


\section{TARGETS FOR GENETIC CONTROL}

Following tissue disruption, lipoxygenase is a key enzyme in the rapid formation of volatiles from lipids. The action of HPL ultimately forms hexanal and cis-3-hexenal. Reduction or isomerization of these compounds by ADH and perhaps an isomerase produces hexanol, cis3-hexenol, and trans-2-hexenal (Galliard et al., 1977; Jadhav et al., 1972; Stone et al., 1975). All but hexanol in this group of volatiles have relatively high log odor units (Buttery, 1993). Conceivably, therefore, regulation of gene expression of LOX, HPL, and ADH might impact tomato fruit flavor. However, homogenation of tomato tissue may exaggerate the importance of lipoxygenase-derived volatiles because of the wounding effect, since wounding also induces formation of this enzyme (Hildebrand, 1989).

In a study of activities and subcellular location of LOX and HPL, Riley et al. (1996) reported that the majority of LOX activity was soluble, but the microsomal form of LOX changed most during ripening of tomato fruit. The activity of this isozyme increased between the green and breaker ripening stages and then decreased as the fruit turned red. Most of the HPL activity was found in the microsomal fraction and did not change during ripening. Riley et al. (1996) therefore suggested that volatile flavor formation takes place in the microsomal compartment. This was further confirmed by Riley and Thompson (1997), who also suggested that "blebbed" lipid particles (pinched off of membranes) may serve to move flavor volatiles out into the cytosol.

Two genes for LOX, tomlox $\mathrm{A}$ and tomlox $\mathrm{B}$, have been cloned in tomato, using degenerate oligonucleotides corresponding to a purified, partially sequenced (Ferrie et al., 1994), membrane-associated LOX of $\approx 97-\mathrm{kD}$ (Bowsher et al., 1992) by probing breaker fruit cDNA library. TomloxA is expressed in seeds and fruit, reaches its highest level in fruit during the breaker stage and corresponds to the membrane-associated LOX. Tomlox $\mathrm{B}$ is fruit-specific and reaches its highest level in ripe fruit. Another report describes two LOX activities in tomato fruit pericarp that increase in early stages of ripening and subsequently decrease, roughly paralleling ethylene production. The activities were associated with proteins of 95- and 97-kD (Ealing, 1994).

A 94-kD LOX was purified and cloned from a red-ripe fruit cDNA library (Kausch and Handa, 1997); it corresponded with a 94-kD protein that accumulated in the fruit during ripening, and reached a maximum concentration at the red-ripe stage. Expression of this gene was highest in the radial pericarp, but the highest LOX activity was in the locular gel, suggesting that LOX might have been synthesized in the pericarp and transported to the locular tissue where it accumulated during ripening. Buttery et al. (1988) reported that levels of hexanal, cis-3-hexenal, and cis-3-hexenol in the locular fluid of dissected fruit was $50 \%$ to $>100 \%$ that of levels in intact fruit. The pulp contained $>100 \%$ of the levels found in the intact fruit for these volatiles. This increase in volatile concentrations during or following dissection was attributed to wounding (Buttery et al., 1988). Interestingly, the 94-kD LOX gene was not expressed in the nonripening (nor) mutant, whereas the never-ripe $(\mathrm{Nr})$ mutant accumulated the LOX mRNA, but not the protein. Nonexpression in nor fruit indicates that expression of the 94$\mathrm{kDLOX}$ is linked to the ripening process. Since the $N r$ mutation blocks ethylene perception (Lanahan et al., 1994), accumulation of the LOX mRNA, but not the protein, indicates that ethylene may play a role in posttranscriptional regulation of the 94-kD LOX, perhaps through translation, or that ethylene affects the stability of the protein. Apparently ethylene perception is not required for gene expression and subsequent mRNA accumulation. The ability to synthesize hexanal, cis-3-hexenal, cis-3-hexenol, and trans-2-hexenal increases during ripening, peaking at the pink to red-ripe stage, and is closely associated with ethylene production (Fig. 2) (Baldwin et al., 1991a).

Another important enzyme is $\mathrm{ADH}$, which reduces hexanal and cis-3-hexenal to hexanol and cis-3-hexenol, respectively. Two genes for ADH have been identified in tomato. One (adh1) is expressed in developing seed and pollen and responds to anaerobic stress (Longhurst et al., 1990). Hypoxic conditions are well known to increase ADH gene transcription in many plant parts (DeLisle and Ferl, 1990). The other $(a d h 2)$ is expressed in a range of tissues, including the fruit, and responds to anaerobic stress but also increases during ripening in the presence of normal oxygen levels. The $a d h 2$ gene product is present in tomato pericarp $15 \mathrm{~d}$ prior to the initiation of ripening. The activity decreases and then increases late in ripening. Changes in cytoplasmic $\mathrm{pH}$ may induce ADH activity, since anaerobic stress is not a factor during tomato fruit ripening (Longhurst et al., 1990). A recent study demonstrated the effect of genetic manipulation of ADH levels in ripening tomato fruit. Tomato plants were transformed with constructs containing a tomato adh 2 cDNA. The resulting fruit, with higher or lower levels of ADH activity, exhibited corresponding higher and lower levels of hexanol and cis-3-hexenol. Fruit with increased levels of these alcohols were rated higher in "ripe fruit" flavor by a sensory panel (Speirs et al., 1998).

In one study, alteration of the fatty acid composition of tomato fruit led to changes in the flavor profile (Wang et al., 1996). Overexpression of the yeast $\Delta-9$ desaturase gene increased concentrations of unsaturated and saturated fatty acids in transformed tomato fruit, some of which are precursors of important flavor volatiles. The most dramatic increases were in levels of palmitoleic acid (16:1), 9,12hexadienoic acid (16:2), oleic acid (18:1), and linoleic acid (18:2), the latter being a precursor of hexanal. Because of the increased LOX substrates, transformed plants produced fruit with higher levels of hexanal and hexanol. This was expected since higher levels of hexanal precursor (linoleic acid) were present . Surprisingly, fruit from transformed plants also had higher levels of linolenic acid peroxidation products, such as cis-3-hexenal, trans-2-hexenal, and, subsequently, cis-3-hexenol via ADH.

\section{CONSEQUENCES OF GENETIC CONTROL}

Down-regulation of cell wall-digesting enzymes, such as polygalacturonase (PG) and pectinmethylesterase (PME), can alter the cell wall structure of tomato fruit. The enzyme PME demethylates pectin and PG hydrolyzes mainly demethylated pectin (Huber, 1983; Pressey and Avants, 1982). Transformation of fruit with the antisense genes for these enzymes inhibited PG to $<1 \%$ of the normal level, extended shelf life, and increased disease resistance and solids content (Hobson and Grierson, 1993; Kramer et al., 1992; Schuch et al., 1991). Because cell wall structure can impact aroma binding and release, we assessed, in a preliminary study, the release of flavor volatiles into the headspace of homogenates prepared from transgenic, ripe tomato fruit with down-regulated PG, PME, and PG + PME activities (Table $4 \mathrm{~A}$ and $\mathrm{B}$ ). The flavor volatile data from transgenic fruit, obtained by the method of Baldwin et al. (1992a), are shown as percentages of the values for nontransformed fruit. In the first study (Table 4A), red-ripe tomatoes with down- regulated PG (Kramer et al., 1992; Sheehy et al., 1988) produced lower levels of some volatiles, including methanol, ethanol, 1-penten-3-one, hexanal, 2+3-methylbutanol, trans-2-hexanal, trans2-heptenal, 6-methyl-5-hepten-2-one, cis-3-hexenol, 2isobutylthiazole, and geranylacetone, than did nontransformed fruit. In the second study (Table 4B), transformation of 'Ailsa Craig' fruit down-regulated PG (pTOM 6) (Grierson and Schuch, 1993; Smith et al, 1988) and reduced PME (PE1) (Hall et al., 1993) and PG+PME activities. In this case, the levels of flavor volatiles were similar to those of nontransformed controls except for a reduction in methanol in antisense PME and PG+PME fruit (Table 4B). Thus, at least some of the methanol observed in the headspace of homogenized tomato fruit (Baldwin et al., 1991a, 1991b) comes from demethylation of cell walls by PME once enzyme and substrate are mixed upon cell disruption. Nisperos-Carriedo and Shaw (1990) also suggested that this was the source of the methanol observed in the headspace of orange [Citrus sinensis (L.) Osbeck] juice, which also has active PME. Fruit with down-regulated PG+PME also exhibited low levels of 2+3methylbutanol, 2-isobutylthiazole, and 6-methyl-5-hepten-2-one, the first two of which are derived from amino acids (Table 3 ). The third is thought to arise from carotenoid breakdown (Buttery and Ling, 1993b) and is similar in structure to geranylacetone (one isoprene unit difference between the two compounds), which was at normal levels in the transformed fruit. Despite their apparently similar origin, these two volatiles often behave differently, indicating a possible alternate mechanism for biosynthesis of 6-methyl-5-hepten-2-one. For ex- 
Table 4. Tomato flavor volatiles in ripe homozygous and heterozygous transgenic fruit expressed as a percentage of concentrations in non- transformed controls (NT) including antisense PG (AS-PG), antisense ACC (AS-ACC) and its hybrid (AS-ACC x NT), antisense PME (AS-PME), antisense PG+PME (ASPG+PME), antisense ACO (AS-ACO), pTOM99 (AS-99), and antisense phytoene synthase (AS-PSY).

\begin{tabular}{|c|c|c|c|c|c|c|c|c|c|c|c|c|c|c|c|}
\hline \multirow[b]{2}{*}{ Fruit type } & \multicolumn{14}{|c|}{ Volatile (\% of nontransformed controls) ${ }^{z}$} & \multirow[b]{2}{*}{ bio } \\
\hline & acet & meoh & etoh & pent & hex & $\mathrm{c} 3 \mathrm{hx}$ & mbut & $\mathrm{t} 2 \mathrm{hx}$ & $\mathrm{t} 2 \mathrm{hp}$ & mhep & c3hol & iso & nphn & ger & \\
\hline \multicolumn{16}{|c|}{ Study $A^{\mathrm{y}}$} \\
\hline AS-PG & 79 & 59 & 56 & 67 & 39 & 123 & 49 & 68 & 54 & 46 & 53 & 50 & 77 & 61 & 218 \\
\hline AS-ACC $\times$ NT & 67 & 87 & 74 & 60 & 80 & 105 & 49 & 69 & 69 & 48 & 65 & 60 & 77 & 55 & 173 \\
\hline \multicolumn{16}{|c|}{ Study $B^{\mathrm{x}}$} \\
\hline AS-PG & 85 & 79 & --- & 100 & 108 & 104 & 102 & 125 & --- & 85 & 167 & 100 & --- & 118 & 102 \\
\hline AS-ACO & 78 & 82 & --- & 78 & 121 & 117 & 31 & 74 & --- & 52 & 108 & 100 & --- & 73 & 150 \\
\hline AS-99 & 113 & 104 & --- & 82 & 108 & 77 & 83 & 138 & --- & 107 & 175 & 200 & --- & 148 & 271 \\
\hline AS-PSY & 54 & 92 & 53 & 80 & 140 & 172 & 58 & 104 & 66 & 56 & 50 & 35 & 69 & 14 & 16 \\
\hline
\end{tabular}

${ }^{2}$ Volatiles analyzed: acetone (acet), methanol (meoh), ethanol (etoh), 1-penten-3-one (pent), hexanal (hex), cis-3-hexenal, (c3hx), 2+3- methylbutanol (mbut), trans2-hexenal (t2hx), trans-2-heptenal (t2hp), 6-methyl-5-hepten-2-one (mhep), cis-3-hexenol (c3hol), 2-isobutylthiazole (iso), 1-nitro-2-phenylethane (nphn), geranylacetone (ger), and $\beta$-ionone (bio).

${ }^{\mathrm{y}}$ Data are means of two samples, each a composite of three ripe fruit, harvested field ripe.

${ }^{x}$ Data are means of three to five samples, each a composite of two to three ripe fruit, harvested $6 \mathrm{~d}$ past breaker stage; "---" indicates not measured.

ample, this compound did not increase following cell disruption, as did geranylacetone (Buttery and Ling, 1993a), and was a product of glycoside hydrolysis, whereas geranylacetone was not (Buttery et al., 1990).

One way to extend shelf life is to delay or reduce ethylene production. Transformed fruit with down-regulated key enzymes in the ethylene biosynthesis pathway exhibited extended shelf life (Murray et al., 1993; Oller et al., 1991). Ethylene is synthesized from $S$ adenosyl methionine via the intermediate, 1-aminocyclopropane-1carboxylic acid (ACC), by action of ACC synthase; ACC in turn, is oxidized to ethylene via ACC oxidase (ACO, also known as ethyleneforming enzyme) (Adams and Yang, 1979; John, 1997). Fruit in which expression of ACC synthase is inhibited (Oeller et al., 1991) produce only $1 \%$ to $5 \%$ of normal ethylene levels and do not ripen completely without treatment with exogenous ethylene. Fruit in which ACO expression is inhibited (Hamilton et al., 1990) produce only $3 \%$ of normal ethylene levels, yet ripen slowly, especially if left on the plant. Ripening can be accelerated by treatment with exogenous ethylene (Murray et al., 1993). Gene pTOM99, which is identical to E8 (Slater et al., 1985), is reportedly regulated by both ethylene and other fruitripening signals. Meanwhile, the gene appears to negatively regulate ethylene biosynthesis (Deikman, 1997; Penarrubia et al., 1992). Since ethylene production often correlated with synthesis of pigments and flavor volatiles (Baldwin et al., 1991a; Buttery, 1993), we investigated the effect of altered ethylene production on levels of flavor volatiles.

In one study, red-ripe fruit with down-regulated ACC synthase (Oeller et al., 1991) produced lower levels of all volatiles measured except cis-3-hexenal, 1-nitro-2-phenylethane, and $\beta$-ionone (Table 4A). Hybrid fruit, resulting from a cross between plants with antisense ACC synthase and nontransformed plants, generally showed levels of volatiles intermediate between those of the two parents. The differences between ACC nontransformed control, hybrid, and antisense ACC fruit were significant $(P \leq 0.05)$ for nine volatiles (Baldwin et al., unpublished). Transgenic fruit had less red color development, as evidenced by lower " $a$ *" values when measured by a chromameter by the method of Baldwin et al. (1991a) than did nontransformed fruit. The hybrid fruit again showed " $a$ *" values intermediate between those of the two parents $\left(\mathrm{a}^{*}=3.1,4.0\right.$, and 6.8 for the transformed, hybrid, and nontransformed fruit, respectively). Levels of the major sugars, glucose and fructose, as analyzed by HPLC (Baldwin et al., 1991a, 1991b), were similar in transformed, hybrid, and nontransformed fruit (Baldwin et al., unpublished).

Fruit from the transgenic 'Ailsa Craig' line (same line as the antisense PG, PME, and PG+PME in Table 4B) exhibited less activity of ACO (pTOM13) (Hamilton et al., 1990; Murray et al., 1993), a key enzyme for the formation of ethylene, and had longer shelf life (Murray et al., 1993; Picton et al., 1993). Volatile production was little affected except for reduction in 2+3- methylbutanol and 6-methyl-5hepten-2-one (Table 4B). Fruit with the antisense gene pTOM99 produced normal to high levels of flavor volatiles. The antisense ACC synthase fruit from the first study and the antisense ACO and pTOM99 fruit from the second study all had abnormally high levels of $\beta$-ionone.

Phytoene synthase (PSY) is a key enzyme in the synthesis of phytoene, a precursor of carotenoids (Gross, 1991). Down-regulation of this enzyme in pTOM5 tomatoes resulted in fruit with no red color (Bird et al., 1991). This resulted in negative " $a *$ " values when measured with a chromameter $\left(\mathrm{a}^{*}=-4.0\right.$ and +6.4 for antisense PSY and nontransformed control fruit, respectively). Analysis of flavor volatiles from antisense PSY fruit revealed lowered levels of all but methanol and some lipid-derived volatiles (1-penten-3-one, hexanal, cis-3-hexenal, and trans-2-hexenal). Levels of most of the amino acid and carotenoid-derived volatiles were reduced, and in the case of geranylacetone and $\beta$-ionone, to nearly trace levels. Surprisingly, however, 6-methyl-5-hepten-2-one was reduced to only $56 \%$ of the levels in nontransformed controls. This again suggests an alternate route for synthesis of this compound. The levels of eight volatiles, including the amino acid and carotenoid-derived compounds, were significantly higher in nontransformed fruit.

The effects of the various antisense transformations may have been due to repression of a specific gene product, but could also have been related to the site at which the antisense gene was inserted. In the latter case, different transgenic lines could exhibit different volatile levels.

\section{CONVENTIONAL BREEDING AND POSTHARVEST TREATMENTS}

Selecting tomatoes with higher levels of carotenoids may result in higher levels of carotenoid-derived volatiles, such as 6-methyl-5hepten-2-one, $\beta$-ionone, $\beta$-damascenone, and geranylacetone, that have positive or borderline log odor units. Stevens (1970) reported high correlations between certain carotenoid-derived volatiles and specific carotenoids in tomato. Buttery et al. (1988) found that tomato cultivars containing higher levels of carotenoids also contained higher levels of 6-methyl-5-hepten-2-one, geranylacetone, and $\beta$-ionone than did those with lower concentrations of carotenoids. The volatile 6-methyl-5-hepten-2-one was higher in the high lycopene cultivar, geranylacetone was higher in the high lycopene and high $\beta$-carotene cultivars, and $\beta$-ionone was higher in the high $\beta$-carotene cultivar. Tomatoes cultured in vitro were induced to produce more lycopene pigment by addition of 2-(4-chlorophenylthio)triethylamine (CPTA), which resulted in an increase of some carotenoid-derived volatiles (Ishida et al., 1998).

Reducing ethylene production and thereby slowing down the ripening and softening process can also be accomplished using the ripening mutants, including nonripening (nor), ripening inhibitor ( rin), never ripe ( $\mathrm{Nr}$ ), and alcobaca (alc). The mutants rin and nor do not ripen, do not display the climacteric rise in carbon dioxide or ethylene, and contain little PG activity. The rin and nor fruit fail to 
develop normal red color. $\mathrm{Nr}$ fruit will ripen to a deeper red than either rin or nor and may contain low PG activity. Alc fruit have prolonged keeping qualities and can develop a light orange-red color on the plant, but do not ripen off the plant if harvested when mature green (Mutschler and Guttieri, 1987). All of these fruit have been used by breeders in crosses with normal-ripening lines to produce hybrids with extended shelf life characteristics, although rin hybrids have been the most successful commercially. It was generally assumed, as with the antisense PG, ACC, or EFE fruit, that quality of the ripened product would be improved because of the possibility of advanced harvest maturities (past color-break). This was based on work by Kader et al. (1977), where tomatoes ripened past breaker stage had better flavor.

Over the past several years, our laboratories have been analyzing rin hybrids from different sources and with different genetic backgrounds. Hybrids with the rin gene often have a pale red color (Baldwin et al., 1995) and both sensory and volatile analyses indicated that rin hybrids had lower levels of many important volatiles at the redripe stage (Baldwin et al., 1992a, 1992b, 1995) (Fig. 3A-D). This was true even in fruit harvested past the breaker stage when compared with normal tomatoes harvested mature green (Fig 3A-D). Yet there was no consistent pattern of difference in soluble solids or titratable acidity (Baldwin et al., 1995) (Fig. $3 \mathrm{E}$ and F). Firmness and shelf life, however, were often greater in the hybrids. Sensory work indicated that rin hybrids were ranked lower than other normal fruit by consumer and experienced panels (Baldwin et al., 1995) (Fig. 3E) and were ranked lower in flavor intensity by trained panels (Baldwin et al., 1998, unpublished data). Nevertheless, incorporation of the rin gene into high flavor and color backgrounds may compensate for the rin effect on flavor and color while improving shelf life. Another study showed that both rin and nor hybrid fruit (backcross 6 generation with 'Rutgers') were deficient in volatiles found in 'Rutgers' tomatoes (McGlasson et al., 1987). The author is not aware of published information on flavor or volatile levels in $\mathrm{Nr}$ fruit.

In addition to using antisense technology and ripening-impaired mutants to indirectly improve flavor through advanced harvest maturity, breeders try to select for better-flavored tomatoes. The problem is that identifying objective measurements that signify good flavor is difficult (Baldwin et al., 1998). Which flavor components are important and what are the appropriate levels and balance for good flavor is still not understood. Analysis of flavor compounds in the aromatic component requires expensive equipment and training. Breeders can use sensory analysis, but this is often difficult to perform and requires access to a panel and considerable expertise. Even sensory descriptive data are limited in applicability as they provide information on specific flavor characteristics, but do not indicate consumer acceptability (Shewfelt, 1993). Nevertheless, significant differences exist between
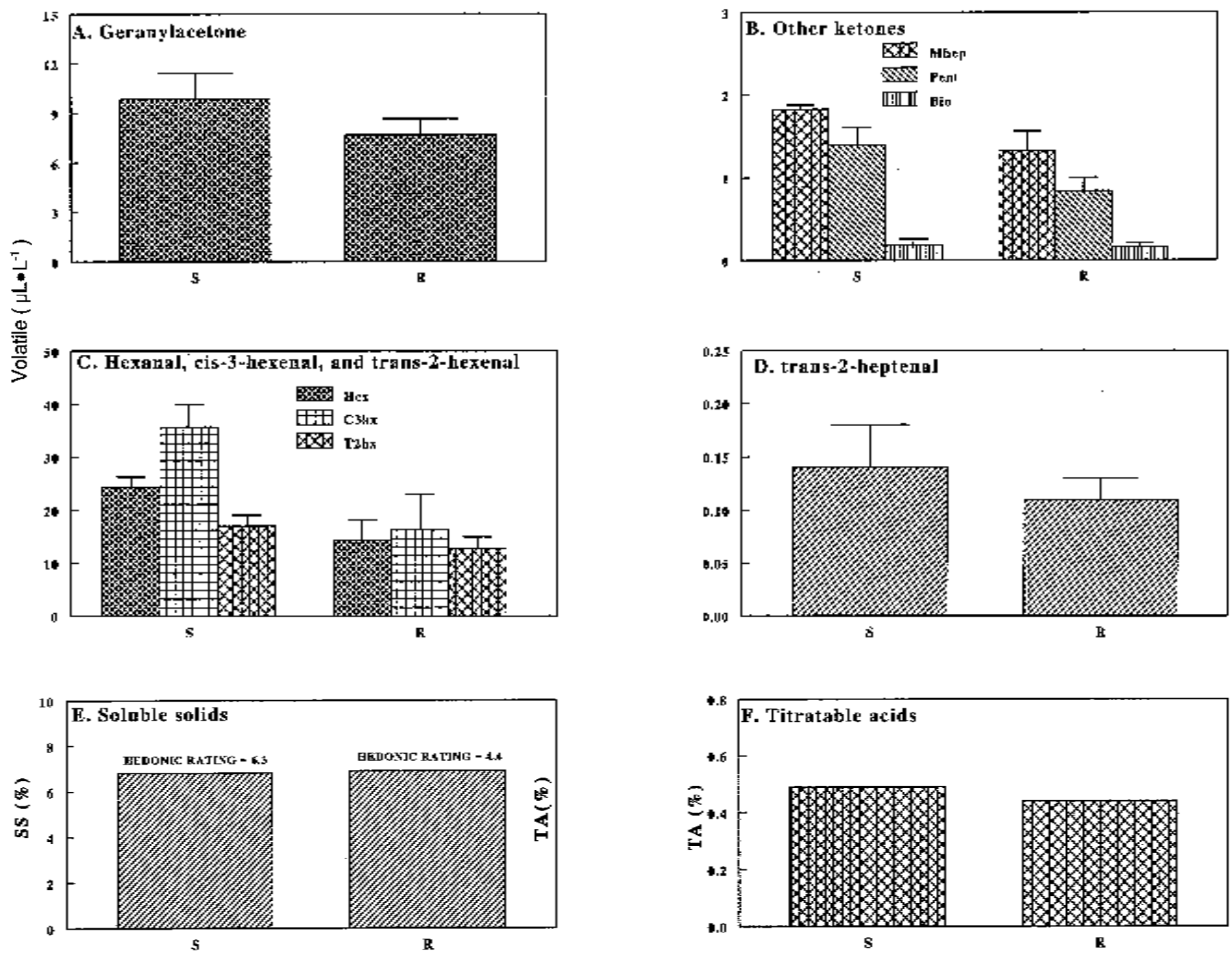

Fig. 3. Headspace ketone volatiles (A) geranylacetone (Ger), (B) 6-methyl-5-hepten-2-one (Mhep), 1-penten-3-one (Pent), and $\beta$-ionone (Bio); headspace aldehyde volatiles (C) hexanal (Hex), cis-3-hexenal (C3hx), trans-2-hexenal (T2hx), and (D) trans-2-heptenal (T2hp) in homogenates of 'Solar Set' (S) tomato harvested mature green and in a rin hybrid (R) harvested at breaker stage; and (E) soluble solids (SS) and (F) titratable acidity (TA) in homogenized fruit tasted by 28 experienced panelists and rated on a hedonic scale of 1 to 9 for overall flavor $(\mathbf{E})$. Data for $(\mathbf{A}-\mathbf{D})$ are means of three replicate samples \pm SD, while $(\mathbf{E})$ and $(\mathbf{F})$ represent one composite sample for SS and TA, all from the same fruit (10 fruit/cultivar) sampled by the 28 panelists $(\mathbf{E})$. 
cultivars in levels of important aroma compounds (Baldwin et al., 1991b, 1995).

Climactic and cultural conditions can also affect tomato flavor. For example, heavy rains prior to harvest appear to dilute the concentrations of flavor compounds (Baldwin et al., 1995). Heavy fertilization with nitrogen and potassium reduced sensory analysis scores, and increased levels of titratable acidity, soluble solids, and several volatiles (including hexenal, phenylacetaldehyde, $\beta$-ionone, and 6-methyl-5hepten-2-one among others) in tomato fruits (Wright and Harris, 1985). Levels of 12 out of 15 volatiles were determined to be higher in field-grown tomatoes than in greenhouse-grown fruit (Dalal et al., 1967)

Finally, harvesting and handling techniques impact the flavor of the ripened tomato fruit. The immature green fruit (determined nondestructively by number of days to break color under ethylene treatment) that can make up a significant percentage of the harvest in a gas green operation, do not ripen with acceptable flavor, as evidenced in sensory and volatile data (Maul, 1999; Maul et al., 1998ab). Bruising of fruit during harvest and handling also alter aroma volatile profiles (Maul et al., 1997; Moretti et al., 1997). Certain volatiles that increase in controlled atmosphere storage $\left(5 \% \mathrm{O}_{2}\right.$ and $\left.4.4 \% \mathrm{CO}_{2}\right)$ do not do so in air storage (Crouzet et al., 1986). Temperature abuse is also a problem that could be controlled. Temperatures below $16^{\circ} \mathrm{C}$ may impair tomato flavor by lowering the volatile content and reducing "tomato-like" flavor (Kader et al., 1978). Storage at 2, 5, 10, 12.5 and $13{ }^{\circ} \mathrm{C}$ reduced levels of important volatiles (Baldwin et al., 1992b; Buttery et al., 1987; Maul, 1999). The mechanism by which volatile levels are reduced is not known, but could be related to reduced ethylene synthesis at low temperatures. Tomatoes stored at $2,5,10$ or $12.5^{\circ} \mathrm{C}$ also had less ripe aroma and tomato flavor, as well as more offflavor, when analyzed by a trained descriptive panel (Maul, 1999).

More studies are needed to really understand the effects of climate, and of cultural and postharvest handling practices on tomato flavor. Nevertheless, poor flavor quality in tomato appears to be a result of breeding practices that do not select for flavor (because of lack of information), harvesting of green fruit (because of prevalence of immature green fruit in commercial harvests), and temperature abuse (because of storage of fruit below $16^{\circ} \mathrm{C}$, which results in impaired volatile levels). Harvest and handling practices could conceivably be altered, but information on flavor for use by breeders and molecular biologists is lacking. Considerable progress has been made in the identification of important flavor components in tomato and the determination of their concentrations in fresh fruit. Additional information is needed, however, on the optimal ranges and ratios for sugars, acids and aromatics required for good flavor. Future work needs to address what instrumental and sensory methods are most effective for evaluating important tomato flavor components. Likewise, establishing the relationship between instrumental measurements and sensory analysis is essential and will allow a more reliable assessment of the effects of breeding, genetic transformation, harvest maturity and postharvest handling on product quality.

The biosynthetic pathway for lipid-derived volatiles has been largely determined, but specific information is lacking on enzyme systems and other possible mechanisms of formation of amino acid and carotenoid groups. This information is necessary for the pragmatic manipulation of levels of flavor volatiles in the fruit. The relationship between volatile formation and ethylene-induced ripening events is not clearly understood, although lipoxygenase appears to be linked to such events. This enzyme may require posttranscription regulation by ethylene as well (Kausch and Handa, 1997). Ethylene is necessary for normal carotenoid development and, thus, may at least indirectly control synthesis of carotenoid-derived volatiles. Control mechanisms for amino acid-derived and other miscellaneous volatiles are little understood.

Thus far, flavor quality for tomato (or any other horticultural product) has been an elusive trait. We still lack quantifiable definition for tomato flavor. Increased performance of analytical instruments, availability of new sensor technology, advances in biotechnology, and development of powerful computer programs make identification and quantification of important chemical components possible. Furthermore, these components can then be traced back to sensory descrip- tors, key enzymes, and gene products. Ultimately, identification and isolation of genes that influence eating quality would be useful. Integrating the fields of plant breeding, molecular biology, postharvest physiology and food science should provide superb opportunities for major breakthroughs in this area.

\section{Literature Cited}

Acree, T.E. 1993. Bioassays for flavor, p. 1-20. In: T.E. Acree and R. Teranshi (eds.). Flavor science: Sensible principles and techniques. Amer. Chem. Soc., Washington, D.C.

Adams, D.O. and S.F. Yang. 1979. Ethylene biosynthesis: Identification of 1aminocyclopropane-1-carboxylic acid as an intermediate in the conversion of methionine to ethylene. Proc. Natl. Acad. Sci. USA 76:170-174.

Amoore, J.E. 1952. The stereochemical specificities of human olfactory receptors. Perfumer Essential Oils 43:321-323.

Baldwin, E.A., M.O. Nisperos-Carriedo, and M.G. Moshonas. 1991a. Quantitative analysis of flavor and other volatiles and for other constituents of two tomato varieties during ripening. J. Amer. Soc. Hort. Sci. 116:265-269.

Baldwin, E.A., M.O. Nisperos-Carriedo, and J.W. Scott. 1991b. Quantitative analysis of flavor parameters in six Florida tomato varieties (Lycopersicon esculentum Mill). J. Agr. Food Chem. 39:1135-1140.

Baldwin, E.A., M.O. Nisperos-Carriedo, and J.W. Scott. 1992a. Levels of flavor volatiles in a normal cultivar, ripening inhibitor and their hybrid. Proc. Florida. State Hort. Soc., 104:86-89.

Baldwin, E.A., M.O. Nisperos-Carriedo, and J.W. Scott. 1992b. Tomato flavor volatile profiles: Cultivar and harvest maturity effects. Tomato Quality Wkshp. Proc. No. 502:18-29.

Baldwin, E.A., J.W. Scott, M.A. Einstein, T.M.M. Malundo, B.T. Carr, R.L. Shewfelt, and K.S.Tandon. 1998. Relationship between sensory and instrumental analysis for tomato flavor. J. Amer. Soc. Hort. Sci. 123:906-915.

Baldwin, E.A., J.W. Scott, and R.L. Shewfelt. 1995. Quality of ripened mutant and transgenic tomato cultigens. Proc. Tomato Quality Wkshp. Proc. No. 503:47-57

Berger, R.G. 1991. Fruits I, p. 283-304. In: H. Maarse (ed.). Volatile compounds in foods and beverages, Marcel Dekker, New York.

Bird, C.R., J.A. Ray, J.D. Fletcher, J.M. Boniwell, A.S. Bird, C. Teulieres, I. Blain, P.M. Bramley, and W. Schuch. 1991. Using antisense RNA to study gene function: Inhibition of carotenoid biosynthesis in transgenic tomatoes. Bio/technol. 9:635-639.

Bowsher, C.G., B.J.M. Ferrie, S. Ghosh, J. Todd, J.E. Thompson, and S.J. Rothstein. 1992. Purification and partial characterization of a membraneassociated lipoxygenase in tomato fruit. Plant Physiol. 100:1802-1807.

Buttery, R.G. 1993. Quantitative and sensory aspects of flavor of tomato and other vegetables and fruits, p. 259-286. In: T.E. Acree and R.Teranishi (eds.). Flavor science: Sensible principles and techniques. Amer. Chem. Soc., Washington, D.C.

Buttery, R.G., D.G. Guadagni, and L.C. Ling. 1973. Flavor compounds: Volatiles in vegetable oil and oil-water mixtures. Estimation of odor thresholds. J. Agr. Food Chem. 21:198-201.

Buttery, R.G. and L.C. Ling. 1993a. Enzymatic production of volatiles in tomatoes, p.137-146. In: P. Schreier and P. Winterhalter (eds.). Flavor precursors. Allured Publ., Wheaton, Ill.

Buttery, R.G. and L.C. Ling. 1993b. Volatiles of tomato fruit and plant parts: Relationship and biogenesis, p. 23-34. R. Teranishi, R. Buttery, and H. Sugisawa (eds.). Bioactive volatile compounds from plants. ACS Books, Washington, D.C.

Buttery, R.G., R.M. Seifert, D.G. Guadagni, and L.C. Ling. 1971. Characterization of additional volatile components of tomato. J. Agr. Food Chem. 19:524-529.

Buttery, R.G., G.R. Takeoka, and L.C. Ling. 1995. Furaneol: Odor threshold and importance to tomato aroma. J. Agr. Food Chem. 43:1638-1640.

Buttery , R.G., G. Takeoka, R. Teranishi, and L.C. Ling. 1990. Tomato aroma components: Identification of glycoside hydrolysis volatiles. J. Agr. Food Chem. 38:2050-2053.

Buttery, R.G., R. Teranishi, R.A. Flath., and L.C. Ling. 1989. Fresh tomato volatiles: Composition and sensory studies, p. 213-222. In: R. Teranishi, R.G. Buttery, and F. Shahidi (eds.). Flavor chemistry: Trends and developments. Amer. Chem. Soc., Washington, D.C.

Buttery, R.G., R. Teranishi, and L.C. Ling. 1987. Fresh tomato aroma volatiles: A quantitative study. J. Agr. Food Chem. 35:540-544.

Buttery, R.G., R. Teranishi, L.C. Ling, R.A. Flath, and D.J. Stern. 1988. Quantitative studies on origins of fresh tomato aroma volatiles. J. Agr. Food Chem. 36:1247-1250.

Crouzet, J., A. Signoret, J. Coulibaly, and M.H. Roudsari. 1986. Influence of controlled atmosphere storage on tomato volatile components, p. 355-367. In: The shelf life of foods and beverages. Elsevier Science, Amsterdam, The Netherlands. 
Dalal, K.B., L.E. Olson, M.H. Yu, and D.K. Salunkhe. 1967. Gas chromatography of field-, glass-greenhouse-grown, and artificially ripened tomatoes. Phytochemistry 6:155-157.

Deikman, J. 1997. Molecular mechanism of ethylene regulation of gene transcription. Physiol. Plant. 100:561-566.

DeLisle, A.J. and R.J. Ferl. 1990. Transcriptional control of alcohol dehydrogenase genes in plants. Intl. Rev. Cytol. 123:39-60.

De Rovira, D. 1997. Manual-Flavor nomenclature workshop: An odor description and sensory evaluation workshop. Flavor Dynamics, Somerset, N.J.

Ealing, 1994. Lipoxygenase activity in ripening tomato fruit pericarp tissue. Phytochemistry. 36:547-552.

Ferrie, B.J., N. Beaudoin, W. Burkhart, C.G. Bowsher, and S.J. Rothstein. 1994. The cloning of two tomato lipoxygenase genes and their differential expression during fruit ripening. Plant Physiol. 106:109-118.

Galliard, T., J.A. Matthew, A.J. Wright, and M.J. Fishwick. 1977. The enzymic breakdown of lipids to volatile and non-volatile carbonyl fragments in disrupted tomato fruits. J. Sci. Food Agr. 28:863-868.

Grierson, D. and W. Schuch. 1993. Control of ripening. Phil. Trans. Royal Soc. London (B) 342:241-250.

Gross, J. 1991. Carotenoids: Biosynthesis, p. 112-128. In: Pigments in vegetables: Chlorophylls and carotenoids. Van Nostrand Reinhold, New York.

Hall, L.N., G.A. Tucker, C.J.S. Smith, C.F. Watson, G.B. Seymour, Y. Bundick, J.M. Bromwell, J.D. Fletcher, J.A. May, W. Schuch, C.R. Bird, and D. Grierson. 1993. Antisense inhibition of pectin esterase gene expression in transgenic tomatoes. Plant J. 3:121-129.

Hamilton, A.J., G.W. Lycett, and D. Grierson. 1990. Antisense gene that inhibits synthesis of the hormone ethylene in transgenic plants. Nature 346:284-287.

Hildebrand, D.F. 1989. Lipoxygenases. Physiol. Plant. 76:249-253.

Hobson, G. and D. Grierson. 1993. Tomato, p. 405-442. In: G.B. Seymour, J.E. Taylor, and G.A. Tucker (eds.). Biochemistry of fruit ripening. Chapman and Hall, New York.

Huber, D.J. 1983. The role of cell wall hydrolases in fruit softening. Hort. Rev. 5:169-219.

Ishida, B., N.E. Mahoney, and L.C. Ling. 1998. Increased lycopene and flavor volatile production in tomato calyces and fruit cultured in vitro and the effect of 2-(4-chlorophenylthio)triethylamine. J. Agr. Food Chem. 46:45774582.

Jadhav, S., B. Singh, and D.K. Salunkhe. 1972. Metabolism of unsaturated fatty acids in tomato fruit: Linoleic and linolenic acid as precursors of hexanal. Plant Cell Physiol. 13:449-459.

John, P. 1997. Ethylene biosynthesis: The role of 1-aminocyclopropane-1carboxylate (ACC) oxidase, and its possible evolutionary origin. Physiol Plant. 100:583-592

Kader, A.A., L.L. Morris, M.A. Stevens, and M. Albright-Holton. 1978. Composition and flavor quality of fresh market tomatoes as influenced by some postharvest handling procedures. J. Amer. Soc. Hort. Sci. 103:6-13.

Kader, A.A., M.A. Stevens, M. Albright-Holton, L.L. Morris, and M. Algazi. 1977. Effect of fruit ripeness when picked on flavor and composition in fresh market tomatoes. J. Amer. Soc. Hort. Sci. 102:724-731.

Kausch, K.D. and A.K. Handa. 1997. Molecular cloning of a ripening-specific lipoxygenase and its expression during wild-type and mutant tomato fruit development. Plant Physiol. 113:1041-1050.

Kramer, M., R. Sanders, H. Bolkan, C. Waters, R.E. Sheehy, and W.R. Hiatt. 1992. Postharvest evaluation of transgenic tomatoes with reduced levels of polygalacturonase: Processing, firmness and disease resistance. Postharvest Biol. Technol. 1:241-255.

Lanahan, M.B., H.C. Yen, J.J. Giovannoni, and H.J. Klee. 1994. The Never ripe mutation blocks ethylene perception. Plant Cell 6:521-530.

Land, D.G. 1994. Savory flavors-An overview, p. 298-306. In: J.R. Piggott and A. Paterson (eds.). Understanding natural flavors. Blackie Academic and Professional-Chapman and Hall, New York.

Longhurst, T.J., J.F. Tung, and C.J. Brady. 1990. Developmental regulation of the expression of alcohol dehydrogenase in ripening tomato fruits. J. Food Biochem. 14:421-423.

Margot, C. and G. Salvadori. 1995. A century for the senses. Perfumer and Flavorist 20:11-16.

Maul, F. 1999. Harvest maturity and postharvest temperature management can compromise flavor potential of fresh-market tomato (Lycopersicon esculentum Mill). PhD Thesis, Horticulture Dept., Univ. of Florida, Gainesville.

Maul, F., S.A. Sargent, M.O. Balaban, E.A. Baldwin, D.J. Huber, and C.A. Sims. 1998a. Aroma volatile profiles from ripe tomatoes are influenced by phyiological maturity at harvest: An application of electronic nose technology. J. Amer. Soc. Hort. Sci. 123:1094-1101.

Maul, F., S.A. Sargent, M.O. Balaban, D.J. Huber, E.A. Baldwin, and C.A. Sims. 1998b. Predicting flavor potential for green-harvested tomato fruit.
Proc. Florida State Hort. Soc. 111:285-290.

Maul, F., S.A. Sargent, D.J. Huber, M.O. Balaban, D.A. Luzuriaga, and E.A. Baldwin. 1997. Non-destructive quality screening of tomato fruit using electronic nose technology. Proc. Florida. State Hort. Soc. 110:188-194.

McGlasson, W.B., J.H. Last, K.J. Shaw, and S.K. Meldrum. 1987. Influence of the non-ripening mutants rin and nor on the aroma of tomato fruit. HortScience. 22:632-634.

Moretti, C.L., S.A. Sargent, E.A. Baldwin, D.J. Huber, and R. Puschmann. 1997. Pericarp, locule and placental tissue volatile profiles are altered in tomato fruits with internal bruising. 6th Brazilian Congr. Plant Physiol., 10-15 August., Belem, Brazil.

Murray, A.J., G.E. Hobson, W. Schuch, and C.R. Bird. 1993. Reduced ethylene synthesis in EFE antisense tomatoes has differential effects on fruit ripening processes. Postharvest Biol. Technol. 2:301-313.

Mutschler, M.A. and M. Guttieri. 1987. The effects of the alc mutant on tomato ripening, p. 289- 297. In: D.J. Nevins and R.A. Jones (eds.). Tomato biotechnology. Alan R. Liss, New York.

Nisperos-Carriedo, M.O. and P.E. Shaw. 1990. Volatile flavor components of fresh and processed orange juices. Food Technol. 44:134-137.

Oeller, P.W., L. Min-Wong, L.P. Taylor, D.A. Pike, and A. Theologis. 1991 Reversible inhibition of tomato fruit senescence by antisense RNA. Science 254:437-439.

Penarrubia, L., M. Agullar, L. Margossian, and R.L. Fisher. 1992. An antisense gene stimulates ethylene hormone production during tomato fruit ripening. Plant Cell 4:681-687.

Picton, S., S.L. Barton, M. Bouzayen, A.J. Hamilton, and D. Grierson. 1993. Altered fruit ripening and leaf senescence in tomatoes expressing an antisense ethylene-forming enzyme transgene. Plant J. 3:469-481.

Pressey, R. and J.K. Avants. 1982. Solubilization of cell walls by tomato polygalacturonases: Effects of pectinesterases. J. Food Biochem. 6:5774.

Riley, J.C.M. and E. Thompson. 1997. Subcellular generation and distribution of lipid-derived volatiles in ripe tomato. J. Plant Physiol. 150:546-551.

Riley, J.C.M., C. Willemot, and J.E. Thompson. 1996. Lipoxygenase and hydroperoxide lyase activities in ripening tomato fruit. Postharvest Biol. Technol. 7:97-107.

Rouhi, A.M. 1996. Tracing scents to an odor map. Chem. Eng. News. 23:18-20.

Schamp, N. And P. Dirinck. 1982. The use of headspace concentration on Tenax for objective evaluation of fresh fruits, p. 25-47. In: G. Charalambous (ed.). Chemistry of foods and beverages. Academic Press, New York.

Schuch, W., J. Kanczler, D. Robertson, G. Hobson, G. Tucker, D. Grierson, S. Bright and C. Bird. 1991. Fruit quality characteristics of transgenic tomato fruit with altered polygalacturonase activity. Hortscience 26:1517-1520.

Sheehy, R.E., M. Kramer, W.R. Hiatt. 1988. Reduction of polygalacturonase activity in tomato fruit by antisense RNA. Proc. Natl. Acad. Sci. USA 85:8805-8809.

Shewfelt, R.L. 1993. Measuring quality and maturity, p. 100-124. In: R.L. Shewfelt and S.E. Prussia (eds.). Postharvest handling: A systems approach, Academic Press, New York.

Slater, A., M.J. Maunders, K. Edwards, W. Schuch and D. Grierson. 1985. Isolation and characterisation of cDNA clones for tomato polygalacturonase and other ripening-related proteins. Plant Mol. Biol. 5:137-147.

Smith, C.J.S., C.F. Watson, J. Ray, C.R. Bird, P.C. Morris, W. Schuch, and D. Grierson. 1988. Antisense RNA inhibition of polygalacturonase gene expression in transgenic tomatoes. Nature 334:724-726.

Song, J., L. Fan, and R.M. Beaudry. 1998. Application of solid phase microextraction and gas chromatography/time-of-flight mass spectrometry for rapid analysis of flavor volatiles in tomato and strawberry fruits. J. Agr. Food Chem. 46:3721-3726.

Speirs, J., E. Lee, K. Holt, K. Yong-duk, N.S. Scott, B. Loveys, and W. Schuch. 1998. Genetic manipulation of alcohol dehydrogenase levels in ripening tomato fruit affects the balance of some flavor aldehydes and alcohols. Plant Physiol. 117:1047-1058.

Stevens, M.A. 1970. Relationship between polyene-carotene content and volatile compound composition of tomatoes. J. Amer. Soc. Hort. Sci. 95:461-464.

Stone, E.J., R.M. Hall, and S.J. Kazeniac. 1975. Formation of aldehydes and alcohols in tomato fruit from $\mathrm{U}^{14} \mathrm{C}$-labeled linolenic and linoleic acids. J. Food Sci. 40:1138-1141.

Tandon, K.S. 1998. Odor thresholds and flavor quality of fresh tomatoes (Lycopersicumesculentum Mill.). MS Thesis, Dept. Food Sci. and Technol., Univ. of Georgia, Athens.

Taylor, A.J. and R.S.T. Linforth. 1994. Methodology for measuring volatile profiles in the mouth and nose during eating, p. 3-14. In: J. Maarse and D.G. van der Heij (eds.). Trends in flavour research. Elsevier Science, New York.

Teranishi, R. and R.G. Buttery. 1987. The significance of low odor compounds in technology. Wiley, New York.

Teranishi, R., R.G. Buttery, D.J. Stern, and G. Takeoka. 1991. Use of odor 
thresholds in aroma research. Lebensm.-Wiss. Technol. 24:1-5.

Teranishi, R. And S. Kint. 1993. Sample preparation, p. 137-167. In: T.E. Acree and R. Teranshi (eds.). Flavor science: Sensible principles and techniques. Amer. Chem. Soc., Washington, D.C.

Vickers, A. 1977. Structural and mechanical indicators of flavor quality, p. 4550. In: R. Scanlan (ed.). Flavor quality: Objective measurement. ACS Symp. Ser. 51, Amer. Chem. Soc., Washington, D.C.

Voirol, E. and N. Daget. 1987. Nasal and retronasal olfactory perception of a meat aroma, p. 309-316. In: M. Martens, G.A. Dalen, and H. Russwurm (eds.). Flavour science and technology. Wiley, New York.
Wang, C., C.K. Chin, C.T. Ho, C.F. Hwang, J.J. Polashock, and C.E. Martin. 1996. Changes of fatty acids and fatty acid-derived flavor compounds by expressing the yeast d-9 desaturase gene in tomato. J. Agr. Food Chem. 44:3399-3402.

Williams, P.J. 1993. Hydrolytic flavor release in fruit and wines through hydrolysis of nonvolatile precursors, p. 287-308. In: T.E. Acree and R. Teranishi (eds.). Flavor science: Sensible principles and techniques. Amer. Chem. Soc., Washington, DC.

Wright, D.H. and N.D. Harris. 1985. Effect of nitrogen and potassium fertilization on tomato flavor. J. Agr. Food Chem. 33:355-358. 